\title{
课程思政理念下计算机软件技术专业教学改革探索
}

\author{
李书娴 \\ 江苏财会职业学院 \\ DOI:10.32629/er.v3i8.3031
}

\begin{abstract}
[摘要] 我国在近几年强调 “要坚持把立德树人作为中心环节,把思想政治工作贯穿教育教学全过程, 实现全程育人、全方位育人。”的教育理念。专业课程是教学中的重要组成部分和载体,如何把思政教 育融入专业课程的教学中就成为了研究的重点内容。本文主要研究计算机软件技术专业课程中思政教 育融入的实现路径。高校要发掘计算机软件技术专业课程中思政教育的点, 并广泛落实到教学的日常中 去,强化立德树人的意识,充分发挥思政教育在专业课程中的育人功能。
\end{abstract}

[关键词] 课程思政理念; 计算机软件; 教学改革

中图分类号：TP31 文献标识码: A

\section{1 计算机软件技术专业教育强 化思政教育的必要性}

1. 1有利于帮助学生正确认识历史 规律

任何学科专业的发展都有其规律可 以遵循, 计算机软件技术专业课程也不 例外。因此, 要关注计算机软件技术专业 的发展历史, 准确把握计算机所处的发 展阶段, 立足于当下, 展望未来。计算机 软件技术专业课程中融入思政教育有利 于学生掌握和正确认识计算机软件技术 专业课程的特点和发展规律。

1.2 有利于帮助学生树立正确的人 生观

大学是学生的人生观逐渐成熟的重 要阶段, 受到的影响因素比较多, 专业课 的教育在其中占了很大的比例。因此, 在进行计算机软件技术专业课程时要有 效融入思政教育的元素, 共同发挥作用 使学生树立正确的人生观。

1.3 有利于促进学生的综合全面 发展

应用型人才不仅仅应该具备较高的 专业素质, 更需要具备优良的思想政治 素质, 实现自我的全面综合发展。尤其是 职业道德素质的养成, 有利于学生在日 后的职业发展道路上始终保持初心, 保 持底线。在专业教育课程中, 强化思政教 育, 有助于提高大学生的思想道德水平,
增强学生的道路自信、文化自信, 激励学 生全面发展。

\section{2 专业课教学改革思路的实现 和发展}

在思政课程教学过程中要始终坚持 以重要的课程理念为分析标准, 高度重 视专业课程的突出重点思路引导, 从专 业课的多维度以及多角度对思政教育给 予重视, 发挥思政教育在专业课程中的 价值引导作用。高校教师要结合自身的 实际情况以及计算机软件技术专业课程 的教学特点, 转变教学方式, 实现教学的 多元化。依据专业知识传播情况, 以正确 的思路, 调整人生观、价值观、世界观, 在潜在的模式操作中, 不断培养学生良 好的模式标准。对于专业课操作, 需要实 施更加高标准的教育思路和责任意识划 分, 注重教学工具的应用。

思政立德教育是教师履行的重要职 责和依据, 以承担重要使命为基础, 分析 专业课教师、思政教师之间的关系, 力求 共同努力, 助力课堂的思维模式融合, 拓 展课堂课题的研究效果。通过高校采集 的拓展思路, 及时调整措施, 融入思政教 育的专业性, 推动产业化融合发展, 实现 专业课、思政课之间的同时发力提升, 提升二者的有效互补和应用。

“课程思政”模式中, 将所有课程的 功能性落实, 注重专业教师课程教学分
析, 有意识的培养学生的思政教育动态 标准, 确定思政融合内容要素, 结合相关 的知识标准, 传授模式, 提升教师的依托 操作, 注重育人职责的规划, 逐步增强学 生的思政管理理念, 提升职业道德产业 化建设。以创新教学方式方法为标准, 提升教育育人的个性化操作。在师资方 面上, 充分发挥教育教师的互动, 不断促 进双向教育的增长, 有效的落实教育知 识的全面构建, 拓展高校的多元化操作 功能分析, 借助相关方式的融合, 调整思 政教育融合下的发展趋势, 调整培养计 划模式, 加强思政拓展下的复合性人才 的高效应用。

3 计算机软件技术专业课融合 思政教育的途径和发展模式

3.1建立完善的计算机软件硬件匹 配标准

在潜移默化的教育培养过程中, 需 要加强教育培育模式的融合。按照计算 机教育模式教学需求, 注重计算机综合 知识技能分析, 提升爱国教育的认知, 分 解计算机发展模式的进阶变化。依据算 法进行统筹分析, 确定基础计算机软件 技术专业教学标准, 注重计算机软件的 应用, 避免长期使用国外技术, 对本国技 术产生严重的错误观念问题。依据计算 机软件, 尽可能的满足计算机软件技术 专业课程模式教学环境, 引导学生提高 
教学认知, 对计算机的软件应用产生本 国保护意识, 养成良好的思政教育作用 模式。

\section{2 树立健康的网络教育观念}

按照实际明辨思路, 重点分析网络 观念立场, 确定信息价值和理念融合方 案。依托互联网技术应用, 注重信息化的 获取, 确定渠道思路。互联网安全稳定运 行过程中, 需要以有效的计算机网络支 配为标准, 加强教师操作模式下的引导, 帮助学生正确的认识, 确定信息背景下 的思政立场, 帮助学生确定正确的网络 使用观念。按照互联网教育范围, 操作标 准, 推广意义, 注重互联网生活状况、工 作模式、学习标准的深化分析。从网络 环境中确定负责标准, 坚持本身的立场, 确定计算机信息网络的融合, 提升网络 操作的责任划分, 提升多项浏览模式的 融合应用, 组建党建网络, 结合各大网站, 实施有效的思政理念融合, 提升政治素 质建设发展。

\section{3党建文化的网络发展}

促进党建文化的网络化, 在进行思 政教育融入发展时, 党建文化要利用以 计算机为基础的新传媒进行广泛的传 播。注重思政活动落实, 结合关键要素以 及计算机软件技术专业课程的实际教学 需求, 制定完善的计算机软件技术专业 课程, 融入思政内容。在思政教育的带头 管理下, 融合学生的整体知识体系, 并且
反馈到教育实施方案具体的编制过程中 去, 促进学生综合融合拓展。计算机产业 化教育分析中, 需要加强思政教育的应 用, 实施扎实产业知识与能力分析, 坚持 思想意识规划, 结合学生实际情况, 切实 提升教育理念。

3. 4 思政专业课教师的技术培养 提升

按照计算机课程教学融入模式, 注 重思政与计算机软件技术专业内容的融 合, 就需要计算机教师、思政教师在备课 上进行沟通, 分析符合思政专业教育的 操作模式, 建设标准, 技术方法等。通过 思政专业教学分析, 提升技术的培养应 用, 注重产业化的融合应用, 调整操作流 程, 提升操作标准的落实, 满足现代思政 计算机教学的标准要素, 结合相关性, 调 整要点, 实施合理的操作融合, 落实操作 知识。对于知识点进行切入模式操作, 明确符合实际操作的要素和要点。

3.5 专业教学课程育人操作模式的 优化

不断增强专业化的理论融合, 处理 深化思路, 拓展情感融合。坚持马克思列 宁主义的动态指导地位分析, 充分落实 操作功能应用, 加强指导, 确定立场, 确 定方法, 明确观念, 主动实施有效的课程 教学融合, 加强整体专业课程的作用分 析。将思政理论融入到综合产业全面发 展构建中, 实现综合课程建设模式的收
益化拓展。优化专业课程教学育人操作 模式, 依据专业课程构建模式, 加强学 生专业能力的快速培养, 注重关系模式 的融合, 调整引入学生的掌握标准。依 据关键要素, 调整心理特征化额主体发 展水平。

\section{4 结束语}

综上所述, 思政教育与计算机软件 技术专业课程的融合发展符合计算机产 业课程教育教学模式的需求, 与此同时, 也符合综合思政元素的融合拓展。各高 校在开展专业课程的教学活动时要以正 确的政治意识为指导, 将其融入到专业 课程的教学中去, 使学生可以德才兼备, 在进行专业知识学习的同时也促进自身 的全面发展。

\section{[参考文献]}

[1]张晶, 谷云峰. 以立德树人为 引领的高校思想政治理论课教学改 革路径探索 [J]. 渤海大学学报(哲学社 会科学版),2020,42(01):134-138.

[2]李增福.课程思政在高职计算机教学 中的应用研究[J].经济师,2020,(4):181-182.

[3]许慧.课程思政融入高职计算机 应用技术专业的探索及实践 [J].中国信 息技术教育,2020,(Z2):183-184.

[4]郑小平.计算机课程教学融入思 政元素的探索[J]. 卫星电视与宽带多媒 体,2020,(04):222-223. 